\title{
KONSEP HAKI DALAM HUKUM ISLAM DAN IMPLEMENTASINYA BAGI PERLINDUNGAN HAK MEREK DI INDONESIA
}

\author{
Ade Hidayat \\ Dosen Fakultas Syariah dan Hukum \\ Universitas Islam Negeri Sunan Gunung Djati Bandung
}

\begin{abstract}
Abstrak
Dalam hukum ekonomi Islam, Hak Kekayaan Intelektual (HAKI) dikenal dengan sebutan Hak Ibtikar. Hak cipta adalah hak eksklusif bagi pencipta atau penerima hak untuk mengumumkan atau memperbanyak ciptaanya atau memberikan izin untuk itu dengan tidak mengurangi pembatasan-pembatasan menurut peraturan perundang-undangan yang berlaku. Para ulama fiqh sepakat menyatakan bahwa hak kepemilikan mubtakir terhadap hasil pemikirannya dan ciptaannya adalah hak milik yang bersifat material. Namun demikian apabila hak ibtikar tersebut dikaitkan dengan tabi'at mal dapat ditransaksikan, maka ia dapat diwarisi jika pemiliknya meninggal dunia, dan dapat dijadikan wasiat jika seseorang ingin berwasiat. Tulisan ini akan menjelaskan secara ringkas tentang konsep hak kekayaan inetelektual dalam hukum Islam dan implementtasinya bagi perlindungan hak merek di Indonesia.
\end{abstract}

\section{Kata Kunci:}

Hak Kekayaan Intelektual, Ibtikar, Hukum Ekonomi Islam

\section{A. Pendahuluan}

Hak milik dalam hukum ekonomi Islam baik hak milik khusus maupun hak milik umum tidaklah mutlak tetapi terikat oleh ikatanikatan untuk merealisasikan kepentingan orang banyak, mencegah bahaya yakni hal yang membuat hak milik menjadi tugas masyarakat. Sedangkan Hak cipta yang diciptakan seseorang adalah mutlak dimiliki oleh orang yang menciptakannya, hal ini sudah diatur dalam 
undang-undang dan fiqh muamalah yang sudah dibahas sebelumnya, jadi sesorang tidak boleh untuk meniru, menjiplak dan menggandakan hak cipta seseorang tanpa ada persetujuan dari pemilik hak ciptanya, apabila terjadi hal demikian bisa dituntut di muka pengadilan sesuai dengan perundang-undangan yang berlaku.

Persoalan kepemilikan secara historis dimulai ketika manusia berkumpul membentuk suatu komunitas dan berinteraksi untuk memenuhi kebutuhan akan kelangsungan hidupnya (al-hajâh al'udhawiyah). Kegiatan pengaturan harta kekayaan ini menyangkut tiga pilar: konsep kepemilikan; pengelolaan kepemilikan; dan distribusi kepemilikan. Kesemuanya itu ditujukan untuk membangun sebuah sistem ekonomi berbasis etika Islami.

Hak kekayaan intelektual adalah kekayaan yang timbul atau lahir dari kemampuan intelektual manusia, yang menggunakan cipta, rasa, dan karsa untuk melakukan sebuah karya-karya baru, baik di bidang teknologi, ilmu pengetahuan, seni dan sastra. Temuan tersebut dilahirkan atau dihasilkan atas kemampuan intelektual manusia melalui curahan waktu, tenaga, pikiran. Hal inilah yang membedakan kekayaan intelektual dengan jenis kekayaan lainya yang juga dapat dimiliki oleh manusia, tetapi tidak dihasilkan oleh intelektual manusia. Oleh karena itu, tulisan ini akan menjelaskan tentang konsep haki dalam hukum islam dan implementasinya bagi perlindungan hak merek di Indonesia.

\section{B. Pengertian HAKI dalam Hukum Ekonomi Islam}

Pengertian hak dalam Islam ada beberapa pendapat dari para ulama, diantaranya Tengku Muhammad Hasbi ash-Siddieqhy membagi pengertian hak kepada dua bagian, yaitu pengertian secara khusus dan secara umum. Secara khusus didefinisikan sebagai sekumpulan kaidah dan nasih yang mengatur dasar-dasar yang harus ditaati dalam hubungan sesama manusia, baik mengenai orang maupun harta. ${ }^{1}$

${ }^{1}$ Hashbi Ash-Shiddiqiey, Fiqh Muamalah, (Jakarta : Bulan Bintang, 1999), hlm. 20 . 
Secara umum hak diartikan sebagai suatu ketentuan yang dengannya syara' menetapkan suatu kekuasaan atau suatu beban hukum. Adapun definisi hak adalah kekuasaan mengenai sesuatu atau sesuatu yang wajib dari seseorang kepada yang lainnya. sedangkan yang disebut dengan milik adalah kekhususan terdapat pemilik suatu barang menurut syara' untuk bertindak secara bebas bertujuan mengambil manfaatnya selama tidak ada penghalang syar'i. ${ }^{2}$

Secara etimologi, kata milik berasal dari bahasa Arab yaitu almilk yang berarti penguasaan terhadap sesuatu atau sesuatu yang dimiliki (harta). Milik juga merupakan hubungan seseorang dengan suatu harta yang diakui oleh syara', yang menjadikannya mempunyai kekuasaan khusus terhadap harta itu, sehingga ia dapat melakukan tindakan hukum terhadap harta itu, kecuali adanya halangan syara'.

Adapun secara terminologi, ada beberapa definisi al-milk yang dikemukakan ulama fiqh, di antaranya al-milk adalah pengkhususan seseorang terhadap suatu benda yang memungkinkannya untuk bertindak hukum terhadap benda itu (sesuai dengan keinginannya). Artinya, benda yang dikhususkan kepada seseorang itu sepenuhnya berada dalam penguasaanya, sehingga orang lain tidak boleh bertindak dan memanfaatkannya. Pemilik harta bebas untuk bertindak hukum terhadap hartanya, seperti jual-beli, hibah, wakaf, dan meminjamkannya kepada orang lain selama tidak ada halangan dari syara'.

Oleh karena itu Islam tidak mengenal monopoli ilmu pengetahuan, memproteksi sebuah ilmu agar orang lain tidak mengetahuinya. Islam berupaya dan menganjurkan dan memfasilitasi agar tersebarnya ilmu pengetahuan. Ilmu sebagai kekayaan Immateril dalam konsep hak milik, hak milik intelektual adalah hak yang bukan kebendaan. Sedangkan dalam Islam (muamalah) dikenal adanya berbagai macam hak dari seseorang. Namun demikian dalam fiqh

${ }^{2}$ Hendi Suhendi, Fiqh Muamalah, (Jakarta : Raja Grafindo Perkasa, 2002), hlm. 32-33.

${ }^{3}$ Nasrun Haroen, Fiqh Muamalah, Jakarta : Gaya Media Pratama, 2007), hlm. 31 . 
166 | Adliya, Vol. 8 No. 1, Edisi: Januari-Juni 2014

klasik tidak dikenal adanya hak kekayaan intelektual, atau benda yang abstrak. Pembahasan yang ada nampaknya bisa dikaitkan dengan hak milik benda yang abstrak adalah tentang milik atas manfaat benda. ${ }^{4}$

Pada umumnya, terutama di negara-negara berkembang terdapat banyak persoalan di bidang kemasyarakatan. Jika menggunakan pranata-pranata dalam masyarakat sebagai titik tolak, maka dapat diperinci bermacam-macam masalah yang pada waktu ini dapat dianggap sebagai masalah yang cukup gawat. Contohnya dalam masalah hak kepemilikan atau hak cipta, pembajakan dan pelanggaran hak cipta. ${ }^{5}$

Pembajakan dan pelanggaran hak cipta tampaknya telah mendarah daging di masyarakat Indonesia. Terkadang masyarakat sendiri tidak menyadari, bahwa tindakan yang mereka lakukan adalah suatu bentuk pelanggaran hak cipta. Bahkan, kegiatan pelanggaran hak cipta seperti tindakan legal yang setiap orang boleh melakukannya.

Islam memiliki konsep kepemilikan, sesuai dengan firman Allah SW'T, dalam surat Al-Baqarah ayat 284 yang berbunyi :

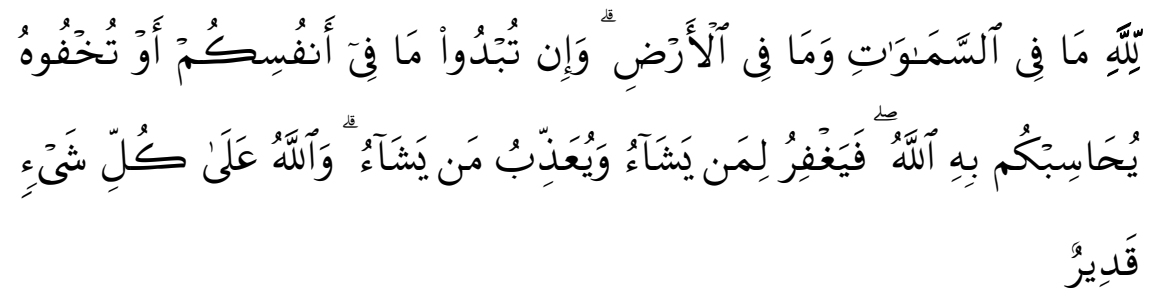

Kepunyaan Allah-lah segala apa yang ada di langit dan apa yang ada di bumi. dan jikea kamu melabirkan apa yang ada di dalam hatimu atau kamu menyembunyikan, niscaya Allah akan membuat perbitungan dengan kamu tentang perbuatanmu itu. Maka Allah mengampuni siapa

4 Penulis mengutip dari Dikutip dari: http:// www.uniska.info.com/ syariah/ attachment142syafrinaldi/ Perbandingan Hak Cipta Dalam Konsep Kapitalis Dengan Hak Milik Dalam Pandangan Islam/ Hukum Islam Vol. III No. 2 Desember 2008, diakses tanggal 4 Juli 2010 6.20 PM).

5 Koentjaraningrat, Metode-metode Penelitian Masyarakat, Jakarta : PT. Gramedia, 1997), hlm. 15. 
yang dikehandaki-Nya dan menyiksa siapa yang dikehendaki-Nya; dan Allah Maha Kuasa atas segala sesuatu. ${ }^{6}$

Selanjutnya pengertian Haqq al-Ibtikar secara etimologi berarti awal sesuatu atau permulaan. Ibtikar dalam fiqh Islam dimaksudkan adalah hak cipta/kreasi yang dihasilkan seseorang untuk pertama kali. Di dalam dunia ilmu pengetahuan al-ibtikar disebut dengan hak cipta. Secara terminologi haaq al-ibtikar dijumpai dalam pembahasan ulama fiqh kontemporer, di antaranya menurut Fathi ad-Duraini yang menyatakan bahwa ibtikar adalah gambaran pemikiran yang dihasilkan seorang ilmuan melalui kemampuan pemikiran dan analisanya. Dan hasilnya merupakan penemuan atau kreasi pertama yang belum dikemukakan ilmuwan sebelumnya. ${ }^{7}$

Islam memandang hak ibtikar yang selanjutnya disebut hak cipta sebagai bagian dari hak kekayaan intelektual, karena hak cipta adalah hak milik pribadi, maka agama melarang orang yang tidak berhak (bukan pemilik hak cipta), baik untuk kepentingan pribadi maupun untuk kepentingan bisnis. Demikian pula untuk meniru atau membajaknya itu dilarang oleh Islam, karena tindakan seperti itu dapat dikatakan sebagai tindak pencurian atau penggelapan. Seseorang bisa melakukan tindakan itu kecuali atas izin penciptanya atau ahli waris yang sah.

\section{Sebab-sebab Hak Kepemilikan dalam Hukum Ekonomi Islam}

Para ulama fiqih menyatakan bahwa ada empat cara pemilikan harta yang diisyaratkan Islam di antaranya: (a) Melalui penguasaan terhadap harta yang belum dimiliki seseorang atau lembaga hukum lainya, contohnya, bebatuan di sungai yang belum dimiliki seseorang atau lembaga hukum; (b) Melalui suatu transaksi yang ia lakukan dengan orang atau suatu lembaga hukum, seperti jual beli, hibah, dan

6 Soenarjo, dkk. Al-Quran dan Terjemabnya, (Jakarta : Depag RI, 1993), hlm. 71.

${ }^{7}$ Penulis mengutip dari http:// www.uniska.info.com/ syariah/ attachment 142 syafrinaldi/Perbandingan Hak Cipta Dalam Konsep Kapitalis Dengan Hak Milik Dalam Pandangan Islam/Hukum Islam Vol. III No.2, Desember 2008, diakses tanggal 4 Juli 2010 6.20 PM). 
wakaf, (c) Melalui peninggalan seseorang, seperti menerima harta warisan dari ahli warisnya yang telah wafat, (d) Hasil/buah dari harta yang telah dimiliki seseorang, selama hasil itu datang secara alami, seperti buah pohon di kebun, dan anak sapi yang lahir.

Persoalan kepemilikan secara historis dimulai ketika manusia berkumpul membentuk suatu komunitas dan berinteraksi untuk memenuhi kebutuhan akan kelangsungan hidupnya (al-hajâh al'udhawiyab). Kegiatan pengaturan harta kekayaan ini menyangkut tiga pilar: konsep kepemilikan; pengelolaan kepemilikan; dan distribusi kepemilikan. Kesemuanya itu ditujukan untuk membangun sebuah sistem ekonomi.

Kepemilikan absolut hanyalah milik Allah, kemudian Allah memberikan wewenang kepada manusia untuk memiliki hak milik dan memberikan izin kepemilikan pada orang tertentu yang sifatnya nyata.

Namun kepemilikan yang diberikan kepada manusia dibatasi oleh hukum dan syariat, contoh kepemilikan harta bergerak (tidak tetap), yang dinisbatkan pada kepemilikan individu, dan kepemilikan harta tidak bergerak (tetap), yang dinisbatkan pada kepemilikan bersama.

Kepemilikan publik adalah seluruh kekayaan yang telah ditetapkan kepemilikannya oleh Allah bagi kaum Muslim sehingga kekayaan tersebut menjadi milik bersama kaum Muslim. Individuindividu dibolehkan mengambil manfaat dari kekayaan tersebut, namun terlarang memilikinya secara pribadi.

Harta berdasarkan sifatnya bersedia dan dapat dimiliki oleh manusia, sehingga manusia dapat memiliki suatu benda. Faktorfaktor yang menyebabkan harta dapat dimiliki menurut Hendi Suhendi antara lain : ${ }^{8}$

1. Ikerar al mubabat, untuk harta yang mubah (belum dimiliki oleh seseorang). Untuk memiliki benda-benda mubahat diperlukan dua syarat yaitu :

a. Benda mubahat belum diikhrazkan oleh orang lain. Seseorang mengumpulkan air dalam wadah, kemudian air

${ }^{8}$ Hendi Suhendi, Fikih Muamalah....op.cit. hlm. 39. 
tersebut dibiarkan, maka orang lain tidak berhak mengambil air tersebut, sebab telah di ikhrazkan orang lain;

b. Adanya niat (maksud) memiliki. Maka seseorang memperoleh harta mubahat tanpa adanya niat, tidak termasuk ikhraz, umpamanya seorang pemburu meletakan jaringnya di sawah, kemudian terjeratlah burung-burung, bila pemburu meletakan jaringnya sekedar untuk mengeringkan jaringnya maka ia tidak berhak memiliki burung-burung tersebut.

2. Khalafiyah ada dua macam, yaitu :

a. Khalafiyah syakbsy'an syakbsy yaitu si ahli waris menempati tempat si muwaris dalam meiliki harta-harta yang ditinggalkan oleh muwaris, harta yang ditinggalkan oleh muwaris disebut tirkah;

b. Khalafiyah syai'an syai'in, yaitu apabila seseorang merugikan milik orang lain atau menyerobot barang orang lain, kemudian rusak ditangannya atau hilang, maka wajiblah dibayar harganya dan diganti kerugian pemilik harta tersebut.

3. Tawallud min mamluk, yaitu segala yang terjadi dari benda yang telah dimiliki, menjadi hak bagi yang memiliki benda tersebut;

4. Karena penguasaan terhadap milik negara atas pribadi yang sudah lebih dari tiga tahun.

Berdasarkan uraian di atas, penulis dapat merumuskan bahwa ketentuan hukum yang berkenaan dengan hak kepemilikan tampaknya sudah diatur dalam hukum ekonomi Islam berdasarkan syaratsyarat dan ketentuan tertentu dan juga dikuatkan oleh pendapat para ahli hukum berdasarkan al-Quran, Sunnah, dan ijtihad.

\section{Macam-macam Hak Kepemilikan dalam Hukum Ekonomi Islam}

Menurut Nasrun Haroen ${ }^{9}$ dalam bukunya Fiqh Muamalah telah menjelaskan macam-macam hak kepemilikan dapat dibagi menjadi dua bagian, yaitu :

${ }^{9}$ Nasrun Haroen, Fikih Muamalah,...op.cit., hlm. 2. 
1. Hak Allah, yaitu seluruh bentuk yang boleh mendekatkan diri kepada Allah, mengagungkan-Nya dan menyebarkan luas ajaran agama-Nya seperti berbagai macam ibadah, jihad, amar makruf nahi munkar, atau dalam rangka mencapai kepentingan dan kemaslahatan umum di alam ini. Seluruh bentuk hak Allah ini tidak boleh digugurkan, baik melalui perdamaian maupun dengan memanfaatkan dan tidak boleh dirubah. Para ulama fiqh menyatakan bahwa hak-hak Allah tidak boleh diwariskan kepada ahli waris;

2. Hak manusia, pada hakekatnya untuk memelihara kemaslahatan setiap pribadi manusia. Dalam hak-hak manusia seseorang boleh memanfaatkan, mengugurkan atau mengubahnya serta dapat diwariskan kepada ahli waris;

3. Hak berserikat (gabungan) antara hak Allah dan hak manusia, tetapi dalam segala hak-hak Allah lebih dominan.

Selanjutnya beliau juga mengemukakan bahwa hak kepemilikan di bagi menjadi dua bagian, yaitu :

1. Al-milk al tamm (milik sempurna), yaitu suatu materi dan manfaat harta itu dimiliki oleh seseorang, misalnya, seseorang memiliki rumah, maka ia berkuasa penuh terhadap rumah itu dan boleh ia manfaatkan secara bebas;

2. Al-milk an-naqish (milik yang tidak sempurna), yaitu seseorang hanya menguasai materi harta itu, tetapi manfaatnya dikuasai orang lain, seperti rumah yang diserahkan kepada orang lain dengan disewakan.

Dalam hal menetapkan dasar hukum hak kepemilikan tampaknya sudah diatur secara gamblang dalam fiqh muamalah, semua orang tidak dengan mudah memnggunakan hak seseorang tanpa aturan yang jelas, semua hak manusia dilindungi oleh aturan dan ketentuan berdasarkan prinsip-prinsip sesuai dengan fiqh muamalah dan undang-undang.

Hak milik individu apabila tidak diakui maka bertentangan dengan fitrah manusia dan menyebabkan kesedihan dan kemalasan, Islam tidak merumuskan bahwa individu dalam usaha merealisasikan kepentingan sebenarnya selalu merealisasikan kepentingan orang banyak, dan selalu terus menerus mendahulukan kepentingan indi- 
vidu atas kepentingan orang banyak. Islam mengakui hak milik pribadi dan pada saat yang sama mengakui hak milik orang banyak.

Hak milik dalam ekonomi Islam baik hak milik khusus maupun hak milik umum tidaklah mutlak tetapi terikat oleh ikatanikatan untuk merealisasikan kepentingan orang banyak, mencegah bahaya yakni hal yang membuat hak milik menjadi tugas masyarakat. Atas dasar itu, maka hak cipta yang diciptakan seseorang adalah mutlak dimiliki oleh orang yang menciptakannya, hal ini sudah diatur dalam undang-undang dan fiqh muamalah yang sudah dibahas sebelumnya, jadi sesorang tidak boleh untuk meniru, menjiplak dan menggandakan hak cipta seseorang tanpa ada persetujuan dari pemilik hak ciptanya, apabila terjadi hal demikian bisa dituntut di muka pengadilan sesuai dengan perundang-undangan yang berlaku.

\section{E. Ketentuan HAKI dalam Hukum Ekonomi Islam}

Kekhasan konsep Islam mengenai hak milik pribadi terletak pada kenyataan bahwa dalam Islam legitimasi hak memiliki tergantung pada moral yang dikaitkan padanya, seperti juga suatu jumlah matematik tergantung pada tanda aljabar yang dikaitkan padanya. Dalam hal ini, Islam berbeda dari kapitalisme dan komunisme, karena tidak satupun dari keduanya itu yang berhasil dalam menempatkan individu selaras dalam suatu mosaik sosial. Hak milik pribadi merupakan dasar kapitalisme, penghapusannya merupakan sasaran pokok ajaran sosial.

Pemilikan kekayaan yang tidak terbatas dalam kapitalisme pasti tidak luput dari kecaman bahwa ia turut bertanggung jawab akan kesenjangan pembagian kekayaan dan pendapatan secara mencolok, karena dalam perkembangan ekonomi sesungguhnya hampir dimana saja ia telah meningkatkan kekuasaan dan pengaruh perserikatan perusahaan. Perusahaan yang memonopoli harga dan produksi, dan perusahaan yang mempunyai hak memonopoli. Hak milik yang tidak ada batasnya ini telah membuat si kaya menjadi kaya dan si miskin menjadi lebih miskin.

Islam memelihara keseimbangan antara hal-hal berlawanan yang terlalu dilebih-lebihkan. Tidak hanya dengan mengakui hak milik pribadi tetapi juga dengan menjamin pembagian kekayaan yang 
seluas-luasnya dan paling bermanfaat melalui lembaga-lembaga yang didirikannya, dan melalui peringatan-peringatan moral. Hal ini akan menjadi lebih jelas jika kita menerangkan ketentuan-ketentuan pokok serta delapan ketentuan khusus syari'at mengenai hak milik kekayaan pribadi dan metode penggunaanya.

Ketentuan Pokok Al-Quran, yang menjadi dasar semua hukum Islam, dengan tegas menyatakan bahwa Allah-lah pemilik mutlak segala sesuatunya, seperti tercantum dalam Al-Quran Surat Ali Imran Ayat 189 yang berbunyi:

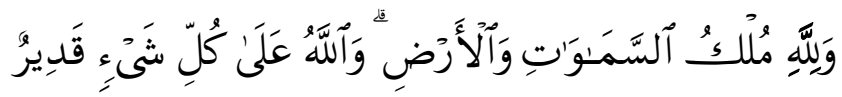

Kepunyaan Allab-lah Kerajaan langit dan bumi, dan Allab Maka Kuasa atas segala sesuatu. ${ }^{10}$

Manusia hanya menjadi khalifah Allah di bumi. Hal ini berarti bahwa Allah menciptakan segala sesuatunya itu untuk Diri-Nya sendiri. Pada Al-Quran dinyatakan: "Dia-lah Allah yang menjadikan segala yang ada di bumi untuk kamu...." (Q.S, Al-Baqarah: 29). Ayat ini menekankan bahwa apa yang telah diciptakan oleh Allah dimiliki secara kolektif oleh seluruh masyarakat Indonesia. Secara hukum hak milik individu adalah hak untuk memiliki, menikmati dan memindah tangankan kekayaan yang diakui dan dipelihara dalam Islam, tetapi mereka mempunyai kewajiban moral menyedekahkan hartanya, karena kekayaan itu juga merupakan hak masyarakat bahkan hewan (Q.S, Adz-Dzariyat: 19).

Ada delapan ketentuan dalam syari'at, penjelasan secara rinci tentang delapan ketentuan syari'at yang mengukur kekayaan pribadi adalah:

1. Pemanfaatan kekayaan. Dalam Islam tidak diperbolehkan memiliki kekayaan yang tidak digunakan, diriwayatkan bahwa Nabi SAW mengatakan: "Orang yang menguasai tanah yang tidak bertuan tidak lagi berhak atas tanah itu jika setelah tiga tahun menguasainya, ia tidak menggarapnya dengan baik". Ajaran mengenai hak milik ini telah dijalankan di masa pemerintahan kahlifah Umar yang konon mengambil kembali

${ }^{10}$ Soenardjo dkk, Al-Quran dan Terjemahnya....opt.cit. hlm. 97. 
beberapa bidang tanah yang telah diberikan Nabi SAW pada Bilal ibn al-Harith, semata-mata karena Bilal tidak memanfaatkan semua lahan yang diberikan oleh Nabi. Aisyah meriwayatkan bahwa Nabi SAW berkata, "Siapa saja yang mengerjakan tanah tak bertuan akan lebih berhak atas tanah itu" (Bukhari). Karena kekayaan yang tidak digunakan merupakan hal yang mubazir dan merugikan pemilik maupun secara keseluruhan, maka negara Islam dapat turun tangan dan mencabut hak atas pemilikan tanah itu. Ketentuan umumnya ialah bahwa kekayaan harus digunakan disemua zaman dengan cara yang benar untuk kebaikan diri sendiri dan juga untuk kebaikan masyarakat;

2. Pembayaran zakat. Ketentuan kedua syari'at mengenai perilaku pemilik kekayaan pribadi ialah ia harus membayar zakat sebanding dengan kekayaan yang dimilikinya. Emas, perak, uang jenis apapun, hasil pertanian, ternak, usaha perdagangan dan apa saja yang dimiliki oleh seseorang selama hidupnya merupakan harta benda yang wajib dizakatkan. Dan siapa saja yang tidak dapat memenuhi kebutuhan-kebutuhan pokoknya dan tidak bisa bekerja adalah fakir dan miskin karena itu tidak wajib zakat. Akhirnya, semua hal yang ditunjukan untuk kebaikan kaum muslimin secara keseluruhan dan bukannya hanya untuk memenuhi kebutuhan-kebutuhan pribadi adalah berbakti di jalan Allah, karena merupakan zakat (Mahmud Shaltut, al-Quddh wa-al Syriat);

3. Penggunaan yang berfaedah. Mengenai perilaku pemilik harta benda pribadi memberi tekanan akan penggunaan berfaedah dari harta benda di jalan Allah, yang berarti semua hal yang berfaedah bagi masyarakat secara keseluruhan mendatangkan kemakmuran dan kesejahteraan. Cara terbaik memanfaatkan harta benda di jalan Allah adalah dengan merumuskan kebijaksanaan pemungutan pajak dari orang-orang kaya yang merupakan sumbangan mereka yang adil untuk meningkatkan kesejahteraan umum. Oleh karena itu pemanfaatan kekayaan di jalan Allah sangat penting karena hal ini adalah salah satu syarat pokok bagi masyarakat untuk menjadi makmur; 
4. Penggunaan yang tidak merugikan. Bila Islam memberikan tekanan pada pemakaian harta benda yang berfaedah berarti membebankan kewajiban pada pemilik harta benda untuk menggunakannya sedemikian rupa sehingga tidak mendatangkan kerugian bagi orang lain atau masyarakat. Pemilikan mutlak segala-galanya ada pada Allah, setiap individu, kaya atau miskin, mempunyai hak untuk menggunakannya. Karena itu, bila kerugian ditimpakan pada orang lain, hal ini akan merupakan pelanggaran terlarang. Islam meningkatkan dasar moral ini dengan menanamkan rasa takut terhadap Tuhan, dalam prakteknya berarti menghindari perilaku anti-sosial dalam segala bentuk dan rupanya secara berhati-hati. Tekanan Islam pada tanggung jawab sosial seorang pemilik harta benda, mempesona para ahli pikir Barat, di antaranya Massignon yang menulis: "Islam berjasa karena konsepsi yang bersifat persamaan mengenai sumbangan masing-masing warga atas haknya akan sumber daya masyarakatnya. Islam memusuhi pertukaran yang tidak terbatas terhadap: modal perbankan, pinjamanpinjaman negara, dan pajak-pajak tidak langsung yang dikenakan pada barang-barang kebutuhan primer. Akan tetapi Islam menghargai hak milik pribadi";

5. Pemilikan yang sah. Ketentuan kelima yang mengatur perilaku pemilik harta benda, tercantum pada Kitab Suci Al-Quran (Q.S An Nisa Ayat 29). Semua tindakan untuk memperoleh harta benda dengan cara-cara melawan hukum dilarang, karena hal-hal ini pada akhirnya merusak suatu bangsa. Mendapatkan harta benda atau barang dagang dengan curang termasuk dalam golongan yang sama. Demikian halnya dengan bila mendapatkan hak milik melalui keputusan pengadilan dengan cara yang tercela seperti penyuapan dan kesaksian palsu adalah suatu perbuatan melanggar hukum. (Q.S Al- Baqarah Ayat 188). Karena masyarakat cenderung bergerak ke arah materialisme, banyak orang berpaling pada cara-cara penipuan, monopoli dan riba untuk menambah kekayaan. Syari'at memberikan kekuasaan penuh pada negara untuk menghukum kegiatan-kegiatan yang tidak jujur. Mengenai monopoli, dalam 
Islam ditentukan bahwa menimbun atau monopoli harta akan dihukum, karena tindakan ini menyebabkan keluarnya kekayaan dari peredaran, dan menjadikan si pemilik dan orangorang lain dalam masyarakat tidak dapat memanfaatkan kekayaan itu;

6. Penggunaan berimbang. Ketentuan keenam syari'at mengenai perilaku pemilik harta benda ialah, ia hendaknya menggunakan harta secara berimbang yaitu jangan boros ataupun kikir. Dalam Al-Quran dinyatakan : "...... Sesungguhnya Allah tidak menyukai orang-orang yang sombong dan membanggabanggakan dirinya. (yaitu) orang-orang yang kikir, dan menyuruh orang lain berbuat kikir, dan menyembunyikan karunia Allah yang telah diberikan-Nya kepada meraka. Dan kami telah menyediakan untuk orang-orang kafir siksa yang menghinakan." (Q.S An Nisa Ayat 36-37). Dengan cara ini Islam mempertahankan keseimbangan dalam menggunakan harta benda. Mengenai pemborosan, dapat dikatakan bahwa harta benda yang diperoleh secara sah menurut hukum merupakan kemurahan hati Allah yang disediakan oleh-Nya untuk keperluan hidup. Semua ini harus dipelihara dengan baik dan jangan diboroskan karena kelalaian;

7. Pemanfaatan sesuai hak. Ketentuan ketujuh, syari'at memberikan tekanan pada pengguna harta benda dengan menjamin manfaatnya bagi si pemilik. Harus diakui bahwa dalam prakteknya orang memanfaatkan mereka untuk kepentingan diri mereka sendiri, baik di bidang poltik maupun di bidang ekonomi dengan mengabaikan kepentingan-kepentingan yang luas bagi masyarakat. Hal ini sangat bertentangan dengan jiwa Islam. Dalam Islam negara harus menjamin bahwa harta tidak akan dipakai untuk mencapai tujuan bagi kepentingan diri sendiri;

8. Kepentingan kehidupan. Karena persoalan pengawasan dan pembagian harta tidak timbul setelah kematian pemiliknya, maka kepentingan bagi mereka yang masih hidup harus terjamin dengan mempraktekkan hukum waris Islam. Dengan mempertimbangkan hukum faktor ini dapat diulangi bahwa 
ciri khas konsep harta Islami terletak pada perintah etika dan moral mengenai hal itu, dengan perintah memberi kesempatan bagi negara Muslim untuk mengatur konsep hak milik pribadi.

Dalam agama Islam terkandung asas-asas yang bila dipahami dan diterapkan dengan baik mungkin dapat merupakan pemecahan terbaik bagi keburukan-keburukan kapitalisme maupun pemecahan terbaik bagi keburukan-keburukan komunisme serta menjamin kebahagiaan dan harta, ketertiban, dan keadilan.

Konsep hak milik pribadi dalam Islam bersifat unik, dalam arti bahwa pemilik mutlak segala sesuatu yang ada di bumi dan di langit adalah Allah (Q.S Ali Imran Ayat 189). Manusia hanyalah khafilah Allah di muka bumi. Pada umumnya terdapat ketentuan syariat yang mengatur hak milik pribadi, yaitu

1. Pemanfaatan harta benda secara terus menerus;

2. Pembayaran zakat sebanding dengan harta benda yang dimiliki;

3. Penggunaan harta benda secara berfaedah;

4. Penggunaan harta benda tanpa merugikan orang lain;

5. Penggunaan harta benda yang sah;

6. Penggunaan harta benda tidak dengan cara boros atau serakah;

7. Penggunaan harta benda dengan tujuan memperoleh keuntungan atas haknya;

8. Penerapan hukum waris yang tepat dalam Islam.

Kekayaan intelektual merupakan kekayaan yang timbul atau lahir dari kemampuan intelektual manusia, yang menggunakan cipta, rasa, dan karsa untuk melakukan sebuah karya-karya baru, baik di bidang teknologi, ilmu pengetahuan, seni dan sastra. Temuan tersebut dilahirkan atau dihasilkan atas kemampuan intelektual manusia melalui curahan waktu, tenaga, pikiran. Hal inilah yang membedakan kekayaan intelektual dengan jenis kekayaan lainya yang juga dapat dimiliki oleh manusia, tetapi tidak dihasilkan oleh intelektual manusia.

Setiap manusia hidup bermasyarakat, saling tolong menolong dalam menghadapi berbagai macam persoalan untuk menghadapi berbagai macam persoalan untuk menutupi kebutuhan antara yang satu dengan yang lainya. Ketergantungan seseorang kepada orang 
lain dirasakan ada ketika manusia lahir. Kemampuan seseorang hanya terbatas pada bidang tertentu saja. Misalnya petani hanya mampu menanam ketela pohon dan padi tetapi tidak dapat membuat cangkul. Jadi petani mempunyai ketergantungan dengan seseorang ahli yang pandai membuat cangkul, begitu juga orang yang pandai membuat cangkul juga memiliki ketergantungan kepada petani.

Kebutuhan sering menimbulkan pertentangan-pertentangan kehendak. Untuk itu perlu adanya aturan-aturan yang mengatur kebutuhan manusia agar manusia itu tidak dapat melanggar hak-hak orang lain, maka timbulah hak dan kewajiban di antara sesama manusia. Hak milik diberi gambaran nyata oleh hakekat dan sifat syari'at Islam sebagai berikut : tabi'at dan sifat syari'at Islam ialah merdeka (bebas) syari'at Islam dalam menghadapi berbagai kemusykilan senantiasa bersandar kepada maslahat (kepentingan umum) sebagai salah satu sumber dari sumber-sumber pembentukan hukum. Corak ekonomi Islam berdasarkan Al-Quran dan As-Sunnah, yaitu suatu corak yang mengakui adanya hak pribadi dan hak umum. Secara etimologi, kata milik berasal dari bahasa Arab yakni al-milk yang berarti penguasaan terhadap sesuatu, milik juga merupakan hubungan seseorang dengan suatu harta yang diakui oleh syara'. Secara terminologi, ada beberapa definisi al milk yang dikemukakan ulama figh, adalah pengkhususan seseorang terhadap suatu benda yang memungkinkannya untuk bertindak hukum terhadap benda itu selama tidak adanya halangan syara'.

Sebenarnya sejumlah permasalahan yang mengemuka tanpa berkesudahan tersebut terjadi akibat ketidakjelasan batas-batas kepemilikan. Islam dengan jelas mendudukkan konsep yang tepat tentang kepemilikan (al-milkiyab). Kepemilikan (property) hakikatnya seluruhnya adalah milik Allah secara absolut. Allah-lah Pemilik kepemilikan dan kekayaan. Firman Allah Q.S Al-Maidah Ayat 17 yang berbunyi:

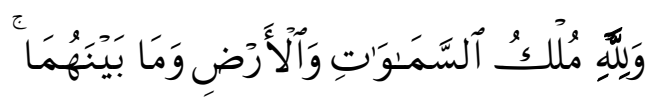


Kepunyaan Allab-lah Kerajaan langit dan bumi serta apa saja yang ada di antara keduanya. ${ }^{11}$

Kemudian Allah SWT memberikan wewenang kepada manusia untuk menguasai (istikblaf) hak milik tersebut dan memberikan izin kepemilikan pada orang tertentu yang sifatnya real. Firman Allah SW'T Surat An-Nur Ayat 33 yang berbunyi:

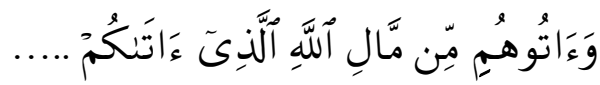

....berikanlah kepada mereka sebagian dari harta Allah yang dikaruniakan-Nya kepadamu... ${ }^{12}$. (Soenarjo, 1993: 549).

Pada kepemilikan ditangan manusia inilah konsep kepemilikan dibedakan. Para pemikir ekonomi Islam berupaya memahami nashnash syari'ah tentang permasalahan kepemilikan ini. Sejak Abu Ubaid menulis Al-Amwâl hingga Al-Kharâj ditulis oleh Yahya Ibnu Adam al-Qurasyi, kesimpulan atas konsep kepemilikan ini belum jelas.

Konsep Islam dalam masalah kepemilikan ini menjadi sangat gamblang ketika Syaikh Taqiyuddin an-Nabhani menulis kitab, AnNizhâm al-Iqtishâdî fî al-Islâm. Syaikh Abdul Qadim Zallum kemudian memaparkannya secara lebih sistematis dalam kitabnya, Al-Amwâl fî Dawlah al-Khilâfah. Dipaparkan bahwa Islam membagi konsep kepemilikan secara jelas: kepemilikan individu (private property); kepemilikan publik (collective property); dan kepemilikan negara (state property).

Kepemilikan publik adalah seluruh kekayaan yang telah ditetapkan kepemilikannya oleh Allah bagi kaum Muslim sehingga kekayaan tersebut menjadi milik bersama kaum Muslim. Individuindividu dibolehkan mengambil manfaat dari kekayaan tersebut, namun terlarang memilikinya secara pribadi. Ada tiga jenis kepemilikan publik:

1. Sarana umum yang diperlukan oleh seluruh warga negara untuk keperluan sehari-hari seperti air, saluran irigasi, hutan, sumber energi, pembangkit listrik, dan lain-lain;

11 Soenardjo dkk, Al-Quran dan Terjemabnya....opt.cit. hlm. 161.

12 Ibid. hlm. 549 
2. Kekayaan yang asalnya terlarang bagi individu untuk memilikinya seperti jalan umum, laut, sungai, danau, teluk, selat, kanal, lapangan, masjid, dan lain-lain;

3. Barang tambang (sumber daya alam) yang jumlahnya melimpah, baik berbentuk padat (seperti emas atau besi), cair (seperti minyak bumi), atau gas (seperti gas alam). Rasulullah saw. bersabda:

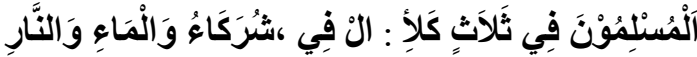

Kaum Muslim sama-sama membutubkan tiga perkara: padang, air dan api. (HR Abu Dawud dan Ibn Majab).

Walaupun akses terhadapnya terbuka bagi kaum Muslim, regulasinya diatur oleh negara. Kekayaan ini merupakan salah satu sumber pendapatan Baitul Mal wa Tamwil (BMT) kaum Muslim. Khalifah, selaku pemimpin negara, bisa berijtihad dalam rangka mendistribusikan harta tersebut kepada kaum Muslim demi kemaslahatan Islam dan kaum Muslim.

Berangkat dari nash tentang ibyâ' al-mawât (revivication), AlKharâj versi Abu Yusuf maupun Ibnu Adam hanya membagi kepemilikan berdasarkan kepemilikan harta bergerak (tidak tetap), yang dinisbatkan pada kepemilikan individu, dan kepemilikan harta tidak bergerak (tetap), yang dinisbatkan pada kepemilikan bersama. Di dalam Al-Mughni, Ibnu Qudamah berkata: Secara global, barang tambang yang nyata dan diperoleh tanpa kesulitan, yang dimanfaatkan oleh publik seperti garam, air, belerang, tir, bahan untuk balsem, minyak tanah, batu celak dan tanah untuk bahan periuk tidak boleh dimiliki oleh sekelompok manusia. Sebab, hal itu bisa menggoyahkan ketenteraman manusia, ditambah dengan alasan Nabi saw. pada hadits Abyadh bin Hammal.

Namun, berbeda statusnya jika bahan tambang itu tersembunyi, yang tidak bisa diperoleh tanpa usaha, seperti emas, perak, besi dan tembaga. Menurut mazhab Syafi'i, jika suatu barang tambang tidak timbul dengan sendirinya atau diperoleh dengan usaha penggalian atau pengeboran, maka ia bisa dimiliki oleh sekelompok manusia, karena tanah itu tanah mati (mawât) yang tidak bisa 
dimanfaatkan kecuali dengan usaha. Artinya, statusnya sama dengan tanah mati yang dihidupkan. Pendapat ini masih menimbulkan kerancuan. Sedangkan menurut Abdul Wahab Khalaf dan Muhammad Abu Zahrah, berkaitan dengan barang tambang di dalam tanah milik privat, pendapat yang terkuat dikemukakan Imam Malik. Semua yang keluar dari perut bumi, berupa batuan dan cairan, adalah milik publik yang diserahkan pengelolaannya kepada negara, dan tidak boleh dikuasai oleh individu.

\section{F. Fungsi HAKI Bagi Perlindungan Hak Merek}

Pada masa sebelum kemerdekaan Indonesia, masalah hak cipta diatur berdasarkan Aurteurswet stb 1912 Nomor 600 . Setelah kemerdekaan Indonesia hak cipta diatur dalam UndangUndang Nomor 6 Tahun 1982 LN. TH. 1982 : No.15. kemudian undang-undang ini diubah dengan Undang-Undang Nomor 7 Tahun 1997 LN. 1997. No. 29, dan terakhir telah diubah dengan lahirnya UU. No. 19 Tahun 2002, untuk selanjutnya disingkat dengan UUHC.

Tahun 1992 UU merk baru diundangkan dan berlaku mulai tanggal 1 April 1993, menggantikan UU merek tahun 1961. Dengan Undang-Undang tersebut surat keputusan administratif yang terkait dengan prosedur merek akhirnya dibuat. Kemudian pada tahun 1997 UU merk tahun 1992 diubah dengan mempertimbangkan pasal-pasal dari perjanjian internasional tentang aspek-aspek yang terkait dengan perdagangan dari hak kekayaan intelektual.

Landasan hukum dari segi formal maupun segi material adalah Pasal 5 ayat 1, Pasal 20 Ayat 1, Pasal 28 Ayat 28C dan Pasal 33 UUD RI Tahun 1945 bidang hukum hak ibtikar ini sangat penting untuk diketahui, karena Indonesia telah ikut serta dalam pergaulan masyarakat dunia menjadi anggota Establisshing The Word Trade Organization.

Indonesia juga meratifikasi Berne Convention for The Protection of Artistic and Literary Work melalui keputusan Presiden RI No. 18 Tahun 1997 dan World Intellectual Property Organization Copyright Treaty 
selanjutnya disebut WTC melalui Keputusan Presiden No. 19 Tahun $1997 .^{13}$

Hak Kekayaan Intelektual atau biasa disebut dengan hak ibtikar terdiri dari hak ekonomi dan hak moral. Hak ekonomi adalah hak untuk mendapatkan manfaat ekonomi akan hak cipta serta produk yang terkait. Sedangkan hak moral adalah hak yang melekat pada diri pencipta atau pelaku yang dapat dihilangkan atau dihapus tanpa alasan apapun walaupun hak cipta atau hak terkait telah dialihkan.

Berdasarkan ketentuan di atas dapat diambil kesimpulan bahwa manusia diciptakan oleh Allah SWT bahwa pada asal mulanya manusia lahir sebagai makhluk yang lemah tidak tahu apa-apa, tidak mempunyai kekuatan dan tidak mempunyai kekayaan apa pun yang lahir dari kandungan ibunya dalam keadaan telanjang, namun karena Allah SWT kemudian memberikan akal dan budi, lalu manusia itu dapat mendengar, melihat dan berfikir.

Negara Indonesia sebagai negara kepulauan memiliki keanekaragaman seni dan budaya yang sangat kaya. Sejalan dengan keanekaragaman etnik, budaya, suku bangsa dan agama yang secara keseluruhan merupakan potensi nasional yang perlu dilindungi. Kekayaan seni dan budaya tersebut adalah merupakan salah satu sumber dari karya intelektual yang dapat dan perlu dilindungi oleh undang-undang kekayaan tersebut tidak semata-mata untuk seni dan budaya itu sendiri, tetapi dapat dimanfaatkan untuk meningkatkan sektor industri, perdagangan dan parawisata dan harus melibatkan penciptanya. ${ }^{14}$

Dalam era perdagangan sekarang ini, hendaknya HAKI atau hak ibtikar terutama hak cipta harus segera didaftarkan, agar setiap pencipta, penemu atau pelaku ekonomi tidak akan mudah dijatuhkan oleh pihak lain. Jadi disini terlihat, bahwa lembaga pendaftaran dan pengakuan hak ibtikar mempunyai peranan penting dalam dunia bisnis. Karena pada dasarnya hak ibtikar pada dasarnya tidak perlu

13 Pipin Syarifin, Dedah Jubaedah, Peraturan Hak Kekayaan Intelektual di Indonesia, (Bandung: Pustaka Bani Quraisy., 2004), hlm.201.

${ }^{14}$ Ibid, hlm. 205-206. 
182 | Adliya, Vol. 8 No. 1, Edisi: Januari-Juni 2014

didaftarkan, namun tetap dilindungi, dalam arti apabila hasil karyanya diumumkan oleh orang yang berhak, maka pada saat itu hak tersebut sudah dilindungi. Hanya saja apabila ada pelanggaran hak ibtikar, sulit untuk membuktikan bagi pemegang hak yang tidak mendaftarkan haknya. Sebaliknya bisa terjadi, orang lain yang mendaftarkan hak tersebut.

Selain itu, pemanfaatan HAKI (hak ibtikar) oleh para penguasa tradisional adalah dalam upaya untuk mempertahankan keaslian produk atau merek barang lokal, menghindari dari penjiplakan hak ibtikar sehingga dengan adanya hak ibtikar kekayaan intelaktual masyarakat terhadap batik tradisional akan terus berkembang dengan baik. Selain itu, juga untuk mempertahankan keaslian batik tradisional, meningkatkan daya saing industri, mempertahankan kualitas produk, strategi promosi, akses saluran distribusi, strategi layanan pelanggan.

Dengan demikian kekayaan seni dan budaya yang dilindungi tersebut dapat meningkatkan kesejahteraan tidak hanya para penciptanya akan tetapi bagi bangsa dan negara. Hak cipta (ibtikar) terdiri dari hak ekonomi dan hak moral. Hak ekonomi adalah hak untuk mendapatkan manfaat ekonomi atas ciptaan produk hak terkait. Sedangkat hak moral adalah hak yang melekat pada diri pencipta atau pelaku yang tidak dapat dihilangkan atau dihapus tanpa alasan apapun walaupun hak cipta atau hak terkait telah dilepaskan.

Perlindungan hak cipta tidak diberikan kepada ide atau gagasan karena karya cipta harus memiliki bentuk yang khas, bersifat pribadi dan menunjukkan keaslian sebagai ciptaan yang lahir berdasarkan kemampuan kreatifitas atau keahlian, sehingga ciptaan dapat dilihat, dibaca atau didengar. Dengan demikian hak cipta/kreasi memenuhi segala persyaratan dari suatu harta dalam fiqh Islam, serta mempunyai kedudukan yang sama dengan harta-harta lainnya yang halal. Oleh sebab itu, para ulama figh, menyatakan bahwa hak cipta/kreasi seseorang harus mendapatkan perlindungan hukum yang sama dengan hak-hak lainnya. 


\section{G. Penutup}

Pada dasarnya hak cipta adalah sejenis kepemilikan pribadi suatu ciptaan yang berupa perwujudan dari suatu ide penciptanya di bidang seni, sastra dan ilmu pengetahuan. Ketika membeli sebuah buku, hanya membeli hak untuk menyimpan dan meminjamkan buku tersebut sesuai dengan keinginan. Buku tersebut adalah hak milik pribadi dalam bentuknya yang nyata atau dalam wujud benda dalam buku. Namun ketika kita membeli buku, kita tidak membeli hak cipta karya tulis yang ada dalam buku yang dimiliki oleh pengarang ciptaan karya tulis yang diterbitkan sebagai buku.

Hak ibtikar bertujuan untuk melindungi ciptaan-ciptaan para pencipta yang dapat terdiri dari pengarang, artis, pelukis batik, musisi, dramawan, pemahat, pemogram komputer dan sebagainya. Hak-hak para pencipta ini perlu dilindungi dari perbuatan orang lain yang tanpa izin mengumumkan atau memperbanyak karya pencipta. Dengan demikian hak cipta didefinisikan sebagai hak eksklusif bagi para penciptanya untuk mengumumkan atau memperbanyak suatu ciptaan atau memberikan izin kepada pihak lainuntuk melakukan hal yang sama dalam batasan hukum yang berlaku. Yang penting untuk diingat adalah hak tadi mengizinkan pemegang hak cipta untuk mencegah pihak lain memperbanyak tanpa izin. Fungsi utama HAKI (Hak Ibtikar) oleh para penguasa tradisional adalah dalam upaya untuk mempertahankan keaslian produk atau merek barang lokal, menghindari dari penjiplakan hak ibtikar sehingga dengan adanya hak ibtikar kekayaan intelaktual masyarakat terhadap batik tradisional akan terus berkembang dengan baik.

\section{DAFTAR PUSTAKA}

Hashbi Ash-Shiddiqiey, Fiqh Muamalah, Jakarta: Bulan Bintang, 1999. Hendi Suhendi, Fiqh Muamalah, Jakarta: Raja Grafindo Perkasa, 2002.

Nasrun Haroen, Fiqh Muamalah, Jakarta: Gaya Media Pratama, 2007. Editor, http:// www.uniska.info.com/ syariah/ attachment 142 syafrinaldi/ Perbandingan Hak Cipta Dalam Konsep Kapitalis 
Dengan Hak Milik Dalam Pandangan Islam/ Hukum Islam Vol. III No. 2 Desember 2008, diakses tanggal 4 Juli 20106.20 PM.

Koentjaraningrat, Metode-metode Penelitian Masyarakat, Jakarta : PT. Gramedia, 1997.

Soenarjo, dkk. Al-Quran dan Terjemahnya, Jakarta : Depag RI, 1993.

Editor, http:// www.uniska.info.com/ syariah/ attachment 142 syafrinaldi/Perbandingan Hak Cipta Dalam Konsep Kapitalis Dengan Hak Milik Dalam Pandangan Islam/Hukum Islam Vol. III No. 2, Desember 2008, diakses tanggal 4 Juli 2010 6.20 PM.

Pipin Syarifin, Dedah Jubaedah, Peraturan Hak Kekayaan Intelektual di Indonesia, Bandung: Pustaka Bani Quraisy, 2004.

Undang-Undang Hak Cipta Nomor 19 Tahun 2002, Bandung : Transito, 2005. 